\title{
901 エキシマレーザーによるセラミックグリーンシート加工
}

Line fabrication for ceramic green seat. with Excimer Laser

○ 中垣 圭太 (山梨大.I)

正管野 善則 (山梨大·工)

Keita NAKAGAKI, Yamanashi University, Takeda-4, Kofu, Yamanashi

Yoshinori KANNO, Yamanashi University

Key Words : excimer laser, laser ablation, ceramics, green sheet

\section{1. はじめに}

様々な製品の性能向上と共に、小型化・高密度化が進む現 在において、微細加工は重要な技術の一つである。微細加工 の手段としてはレーザー加工、切削・研削加工、放電加工、 フォトレジスト等いくつかの種類がある。

その中で、セラミックスはその組成により様々な特性を持 たせることが出来る素材で、ハードディスクの磁気ヘッドス ライダやフィルタ、多層基盤などが挙げられる。しかし、セ ラミックスは高強度で酎磨耗性が高い特徵をもつ反面、加工 性が悪い素材でもある。

そこで、本研究ではセラミックスの微細加工手段の一つと して、 $\mathrm{KrF}$ エキシマレーザーを用いたセラミックスグリーン シートへの微細加工条件を探ってみた。

現在、製品のトレンドとして小型化、高機能化が挙げられ る。製品を構成する部品は、シリコン、樹脂、金属、セラミ ックスといった材料に微細な加工を施したものとなっている。 セラミックスの適応例として多層配線基板、ハードディスク の磁気ヘッドやフィルタなどが挙げられる。しかし、セラミ ックスは微細加エが難しいことから、その適応が十分に進ん でいないことが挙げられている。

そこで、本研究では、セラミックスの微細加工法の一つとし て、 $\mathrm{KrF}$ エキシマレーザによるセラミックスの微細加エを試 みた。

2. 実験方法

Fig.1に本実験で使用したエキシマレーザー加エ装置を示す。

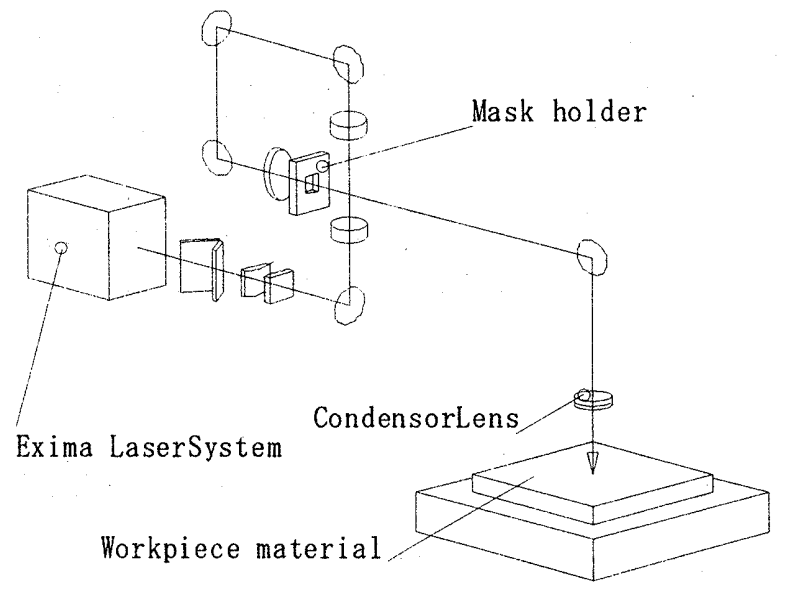

Fig.1 Excimer Laser Machining System

エキシマレーザーシステムは、ラムダ社

製 Compex205 で、 KrF エキシマレーザーの波長 248nm、
パルス幅 25ns のものを用い、繰り返し周波数は $50 \mathrm{~Hz}$ で加エ を行った。

光学系はエキシマレーザーシステム側から順にアッテネータ、 シリンドリカルレンズ、リレーレンズ系、可変ロ径マスク、 集光レンズの順で通しワークピース上に集光させ、必要な箇 所でミラーを用いて光路を届曲させている。

本実験では、集光レンズに 30 分の 1 のものを用い、マスク を $8.1 \mathrm{~mm} \times 1.8 \mathrm{~mm}$ 又は $1.5 \mathrm{~mm} \times 1.5 \mathrm{~mm}$ に設定し、ワークピー ス上でそれぞれ $270 \mu \mathrm{m} \times 60 \mu \mathrm{m}$ 及び $50 \mu \mathrm{m} \times 50 \mu \mathrm{m}$ となるよ うにした。

加工条件として、貫通溝加工に関しては大気中で行った。 非貫通溝加工に関しては、大気中と、窒素ガスを吹きつけな がらの加エを比較してみた。

フルエンスは貫通眻加エで $37 \mathrm{~J} / \mathrm{cm}$ 、非貫通溝加エで $58.48 \mathrm{~J} / \mathrm{cm}$ として行った。

被加工材は、貫通溝加エでは $\mathrm{TiBaO}$ 系のグリーンシート、 非貫通溝加エでは $\mathrm{TiBaO}$ 系と $\mathrm{BaAlSiO}$ 系の二種類のグリーン シートを用いた。

加工面は光学顕微鏡を用いて観察した。

\section{TiBaO 系グリーンシートへの貫通溝加エ}

加エ手順を Fig2 に示す。加エステージ上に陗間をあけて 2 枚 のガラス板を置き、その上にグリーンシートを乗せ、腺間か らグリーンシートを真空チャックで吸引した。

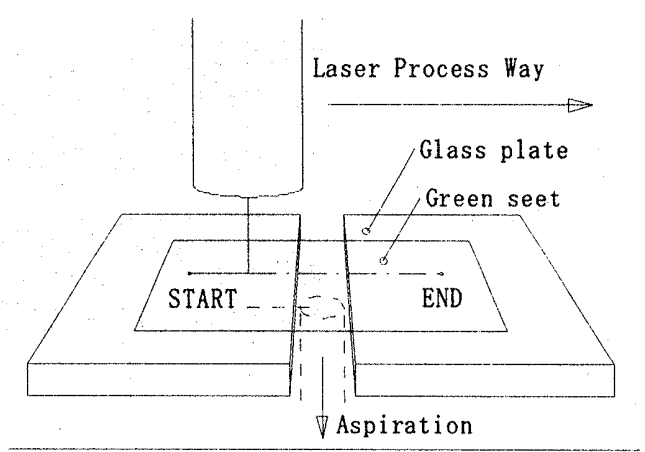

Fig.2 Work sequence

この状態で、グリーンシートを、左側のガラス板上の部分 からレーザー照射を開始し、スキャン速度毎分 $0.1 \mathrm{~mm}$ でワー クピースを動かし、隙間の上を通り右側のガラス板上でレ一 ザ一照射を停止する条件で行った。 
レ一ザーはグリーンシート上で $60 \mu \mathrm{m} \times 270 \mu \mathrm{m}$ の大きさ に絞り、長手方向をグリーンシートの移動方向とし、幅 $60 \mu$ mの貫通淟を作った。

加工後の結果を、Fig.3 Fig.4 Fig.5に示す。

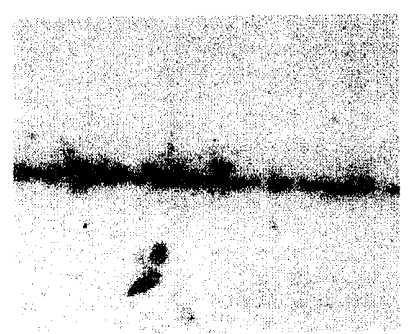

(a)反射光

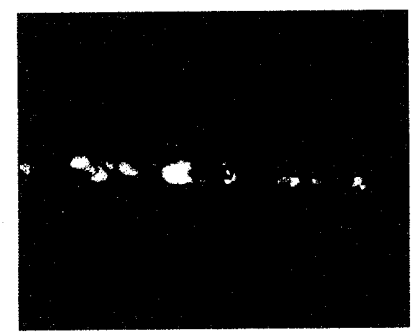

(b)透過光
Fig.3 Optical microscope Image of Green Seet

On start side glass

Fig.3は、レーザー照射を開始した側のグリーンシートを、加 工面の裏側から光学顕微鏡で観察した画像である。透過光で 観察したものを見ると、比較的大きな塊が溝に残っているの がわかる。

この塊は、加工途中に生じた突起が成長し、谷の部分だけ貫 通し、山の部分が多く残ったものと考えられる。

(a)No blow

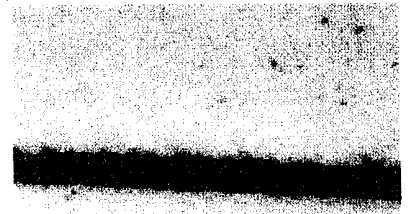

(a)反射光
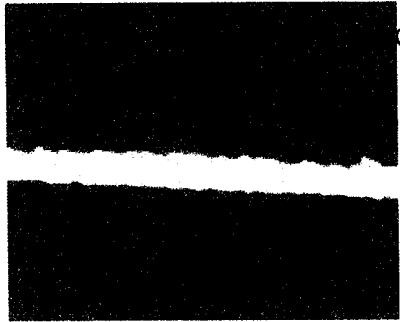

(b)透過光
Fig.4 Optical microscope Image of Green Seet

On between glasses

Fig.4 は、ガラス板の隙間部分を加エした物で、グリーンシー トの下に何も無い事に加え、真空チャックにより吸引してい る為に、加工部に生じた突起が除去されたものと考えられる。

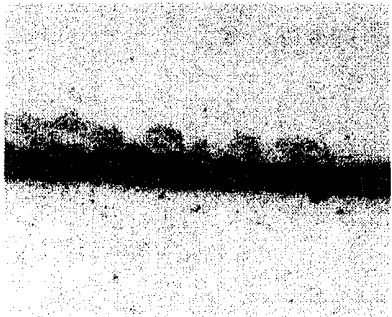

(a)反射光

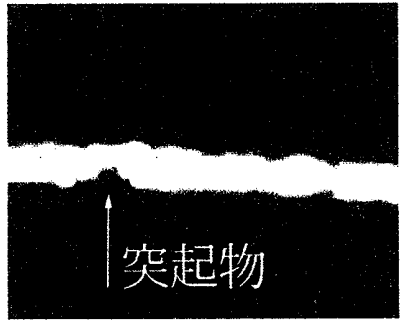

(b)透過光
Fig.5 Optical microscope Image of Green Seet

On end side glass

Fig.5は、レーザー照射を停止した側で、グリーンシートがガ ラス板に乗った部分の写真である。下にガラス板のあるとい う点では Fig.3 と同じ条件であるが、Fig.4 の部分で貫通した 穴部分から、真空チャックにより吸引されることにより生じ た空気の流れと、既に加工が終了した側に乫起等が残ってい ない為に、新たな突起が生成され、残りにくくなっていると 考えられる。

しかし、反射光側で見ると溝の縁の乱れが Fig.4 よりも大き

く、透過光で見ると溝の内部でも、ところどころに比較的大
きな突起物が残っている事がわかる。また、反射光での写真 に見られる、加工部周辺の茶色いしみは、レーザーの過剩照 射による熱影響による変性と思われる。

\section{BaAlSiO の非貫通溝加工}

BaAISiO 系のグリーンシートは、BaTiO 系のグリーンシート に比べると、同一条件での加工性が高く、加工部に焦げが生 じない特徵を持つ。反面、加工部周辺にダストが付着し、溝 の内部にも数十 $\mu \mathrm{m}$ の溶けたガラス質と思われる粒子が生成 されることがある。これらのダストや粒子を軽減する事を狙

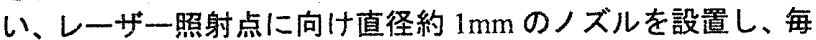
分 $10 \mathrm{~L}$ の流量で窒素ガスを吹き付けてみた。

N2 ガスの吹き付けの有無を Fig.6に示す。
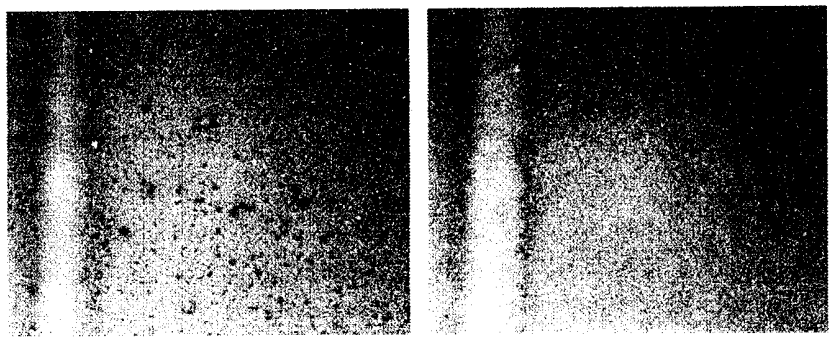

(b)With $\mathrm{N}_{2}$ blow oscope Image of Green seet

Fig.6 (a),(b)共に、左が幅 $50 \mu \mathrm{m}$ の溝である。(a)の窒素ガスの 吹き付け無しで加エしたものには、黒くみえるダストが多く、 所々にガラス質と思われる透明な粒子が付着している。(b)の 窒素ガスを吹き付けた物では、ダスト・粒子共に大幅に少な くなっている。

(b)の溝の中には粒子が写っているが、これはノズルとレー ザ一照射部の位置関係で、溝の内部にまで窒素ガスを吹き付 けることが出来なかったからではないかと思われる。

5. まとめ

本研究では、セラミックグリーンシートへの加エ手法とし て KrF エキシマレーザーを用い、貫通溝・非貫通溝の加工を 行った。

そして、それぞれの加エについて、レ一ザー照射部に対し て空気・窒素ガスの流れを作ることにより、レーザ一照射に より発生したダスト・付着粒子・突起が大幅に軽減されるこ とが分かった。

今後の方針として、非貫通溝加工時において溝の内部にガ スを吹き付けることが出来るように、ノズルの位犆関係を調 節した上でガス流量を調節し、より効率的な加工条件を探る 必要があると思われる。

\section{参考資料}

6. 参考文献

1)M.Mendes, et al:Applied.Surface.Sience,155(2000)29

2)菊地苼,P.W.グリーン,前田龍太郎：機械技術研究所所 報, 51,(1997), 11

3)渡邊 望:山梨講演会論文集,273(2002) 